\title{
Site of aromatic L-amino acid oxidase in dead bovine spermatozoa and determination of between-bull differences in the percentage of dead spermatozoa by oxidase activity
}

\author{
P. Shannon and B. Curson \\ New Zealand Dairy Board Artificial Breeding Centre, Newstead, R.D.4, Hamilton, \\ New Zealand
}

\begin{abstract}
Summary. Most (94\%) of the aromatic L-amino acid oxidase activity in dead bovine spermatozoa was recovered in tail preparations. The enzyme was released from the cell in sodium citrate but not in sodium phosphate or sodium chloride solutions but oxidase activity was not significantly different in sodium phosphate or sodium citrate buffers $\left(9.6 \mu \mathrm{O}_{2} / \mathrm{h}\right.$ and $\left.11.2 \mu \mathrm{O} \mathrm{O}_{2} / \mathrm{h}\right)$. The activity in ejaculated spermatozoa was correlated with the percentage of dead spermatozoa $(r=0.954, P<0.01)$ but could not be detected in freshly collected epididymal spermatozoa. Killed epididymal spermatozoa showed oxidase activity $\left(10.1 \mu \mathrm{O}_{2} / \mathrm{h}\right)$ similar to that of killed ejaculated spermatozoa $\left(9.2 \mu \mathrm{O}_{2} / \mathrm{h}\right)$.

It is concluded that death of spermatozoa occurs in the ampulla and/or at ejaculation and that between-bull differences in the percentage of dead spermatozoa are a consequence of differences between bulls in conditions in the ampulla and/or at ejaculation.
\end{abstract}

\section{Introduction}

Aromatic L-amino acid oxidase (no EC number) is a latent enzyme which is active only after death of bovine spermatozoa (Shannon \& Curson, 1972b). The condition necessary for activation is probably the increased permeability of the sperm membrane associated with senescence and death of the cell (see Mann, 1964: p. 349). Whether activation is dependent on release of the enzyme from the cell, or permeability of the cell to enzyme substrates is not known. Because of the association between activity and dead spermatozoa, enzyme assays are a useful objective biochemical method of determining the proportion of dead spermatozoa in a semen sample. The objectives of the experiments here reported were to determine the sperm site of aromatic L-amino acid oxidase and, by using the assay procedure, determine that region of the male reproductive tract which gives rise to between-bull differences in the percentage of dead spermatozoa.

\section{Materials and Methods}

Determination of oxidase activity

Oxidase activity was measured by the method of Shannon \& Curson (1972b, 1982) which determines oxygen uptake due to L-phenylalanine degradation. 


\section{Site of enzyme}

Semen was centrifuged at $475 \mathrm{~g}$ for $20 \mathrm{~min}$, and the supernatant was discarded. The sperm pellet was then suspended in saline $(9 \mathrm{~g} \mathrm{NaCl} / \mathrm{l})$ at $500 \times 10^{6} \mathrm{spermatozoa} / \mathrm{ml}$. Spermatozoa were disrupted by ultrasonic waves with a Model L, Branson Sonifier (Danbury, Connecticut, U.S.A.). Samples were initially sonicated for $10 \mathrm{sec}$ at setting 10 . They were further sonicated if the disruption of heads from tails was incomplete. An aliquot $(1 \mathrm{ml})$ of the sonicated sperm suspension was layered on to $10 \mathrm{ml}$ of a $7 \%$ Ficoll, $0.15 \mathrm{M}-\mathrm{NaCl}$ solution and centrifuged for 2 min at $350 \mathrm{~g}$. The top 1-ml layer containing the tails was aspirated. Layers from several tubes, usually 10 , were combined and centrifuged for $20 \mathrm{~min}$ at $10000 \mathrm{~g}$. The tails were recovered as a pellet. The separate head and tail pellets were diluted in $0.1 \mathrm{M}$-sodium citrate $(\mathrm{pH} \mathrm{7.0)+0.012}$ M-L-phenylalanine, tails at the equivalent of $50 \times 10^{6}$ spermatozoa $/ \mathrm{ml}$ and heads at $150 \times 10^{6}$ spermatozoa $/ \mathrm{ml}$.

\section{Release of enzyme from spermatozoa}

Three solutions, $0.15 \mathrm{M}$-sodium chloride, $0.1 \mathrm{M}$-sodium phosphate and $0.1 \mathrm{M}$-sodium citrate were tested for their effect on enzyme release from spermatozoa. All solutions were adjusted to $\mathrm{pH} \mathrm{7,} \mathrm{the} \mathrm{sodium} \mathrm{chloride} \mathrm{solution} \mathrm{with} \mathrm{sodium} \mathrm{hydroxide,} \mathrm{the} \mathrm{sodium} \mathrm{phosphate} \mathrm{solution} \mathrm{by}$ appropriate concentrations of mono- and di-basic sodium phosphate, and the sodium citrate solution by citric acid. The effects of these solutions were tested in the following way. Pooled samples of freshly collected semen from 4 bulls were divided into 3 aliquots and centrifuged at $475 \mathrm{~g}$ for $20 \mathrm{~min}$; the seminal plasma was discarded. The sperm pellets were suspended at $500 \times 10^{6}$ ispermatozoa $/ \mathrm{ml}$ in each of the 3 solutions. The spermatozoa were then killed by rapid freezing (Shannon \& Curson, 1972b) and centrifuged at $10000 \mathrm{~g}$ for $30 \mathrm{~min}$. The supernatant was carefully decanted and the sperm pellet was suspended at $50 \times 10^{6} / \mathrm{ml}$ in $0.1 \mathrm{M}$-sodium citrate $+0.03 \mathrm{M}$-L-phenylalanine. The supernatant was dialysed against 10 volumes of $0 \cdot 1$ M-sodium citrate for $24 \mathrm{~h}$, and then diluted $9: 1(\mathrm{v} / \mathrm{v})$ with sodium citrate + L-phenylalanine to give a final composition of $0.1 \mathrm{M}$-sodium citrate $+0.03 \mathrm{M}$-L-phenylalanine.

\section{Effect of buffers on oxidase activity}

After centrifuging semen (475 $\mathrm{g}$ for $20 \mathrm{~min}$ ) spermatozoa were killed by rapid freezing and then suspended in $0.012 \mathrm{M}-\mathrm{L}$-phenylalanine plus $0.15 \mathrm{M}-\mathrm{NaCl}, 0.1 \mathrm{M}$-sodium phosphate, or $0 \cdot 1$ M-sodium citrate at $\mathrm{pH} 7$. They were then assayed for oxidase activity.

\section{Source of between-bull differences in percentage of dead spermatozoa}

Six Jersey bulls aged 5-7 years, all of which exhibited normal service behaviour and with sperm counts greater than $1 \times 10^{9} / \mathrm{ml}$, were selected. Three of the bulls routinely gave semen samples containing $>75 \%$ live spermatozoa and 3 gave samples containing $<50 \%$ live spermatozoa. Before the experiment semen samples were collected 8 times over a period of 2 weeks. The bulls were then rested for 1 week and a single semen sample was collected. The semen was divided into 2 aliquots. One was assayed for oxidase activity within $15 \mathrm{~min}$ of collection, and the spermatozoa in the other were killed by freezing and oxidase activity was assayed. Oxidase activity was measured at $37^{\circ} \mathrm{C}$ with $50 \times 10^{6}$ spermatozoa/ml in $0 \cdot 1$ M-sodium citrate +0.012 M-L-phenylalanine at $\mathrm{pH} 7$. Bulls were then rested for 1 week before cannulation of the vas deferens. There was a flow of epididymal spermatozoa at the time of cannulation which was collected in a warm, lagged test-tube $\left(32^{\circ} \mathrm{C}\right)$. The amount varied from 0.2 to $0.5 \mathrm{ml} /$ bull. Prewarmed $\left(37^{\circ} \mathrm{C}\right)$ sodium citrate $(1 \mathrm{ml}, 0.1 \mathrm{M}, \mathrm{pH} 7)$ was added immediately after collection to prevent drying of epididymal samples on the tube wall. Oxidase 
activity was then assayed for killed and unkilled spermatozoa. In addition to oxidase activity the percentage of dead ejaculated spermatozoa was determined by the nigrosin-eosin staining technique for freshly collected ejaculated semen. Unfortunately, by oversight, this step was omitted with epididymal spermatozoa. Statistical analysis was by methods outlined in Snedecor \& Cochran (1972).

\section{Results}

\section{Site of enzyme}

The summed activity of head and tail preparations from 6 experiments, adjusted to the amount derived from $50 \times 10^{6}$ spermatozoa $/ \mathrm{ml}$, was $9.7 \mu \mathrm{l} \mathrm{O} / \mathrm{h}$ compared to $10.8 \mu \mathrm{l} / \mathrm{h}$ for killed unseparated aliquots of the same semen samples, i.e. approximately $90 \%$ of the oxidase activity was recovered. The oxidase activity of tail preparations was $9 \cdot 1 \mu \mathrm{l} \mathrm{O} / \mathrm{h}$, representing $94 \%(89-98 \%)$ of the recovered activity. Microscopic examination of head preparations always showed some contamination with tails, and the degree of contamination appeared related to the percentage of total activity recovered in head preparations.

\section{Release of enzyme from spermatozoa}

The oxidase retained by spermatozoa placed in the sodium chloride and sodium phosphate solutions was twice that in the sodium citrate solution (Table 1).

Table 1. Effect of solution (all at $\mathrm{pH} \mathrm{7)} \mathrm{on} \mathrm{cell}$ retention of aromatic L-amino acid oxidase in dead bovine spermatozoa $\left(50 \times 10^{6}\right.$ cells $)$

\begin{tabular}{|c|c|c|c|}
\hline \multirow{2}{*}{$\begin{array}{l}\text { Sodium } \\
\text { solution }\end{array}$} & \multicolumn{2}{|c|}{$\mathrm{O}_{2}$ consumption $(\mu \mathrm{l} / \mathrm{h})$} & \multirow{2}{*}{$\begin{array}{l}\% \text { Activity } \\
\text { retained by cells } \\
( \pm \text { s.e.m. })\end{array}$} \\
\hline & In cells & In supernatant & \\
\hline Chloride & $10 \cdot 9$ & 0.6 & $95 \pm 0.2$ \\
\hline Phosphate & 9.8 & 0.6 & $94 \pm 0.2$ \\
\hline Citrate & $4 \cdot 0$ & 5.8 & $41 \pm 2 \cdot 6^{*}$ \\
\hline
\end{tabular}

Values are means for 4 replicates.

* $P<0.01$, compared with the other two buffers.

\section{Effect of buffer on oxidase activity}

The oxidase activity of $50 \times 10^{6}$ dead spermatozoa $/ \mathrm{ml}$ suspended in $0.15 \mathrm{M}$-sodium chloride, $0.1 \mathrm{M}$-sodium phosphate and $0.1 \mathrm{M}$-sodium citrate was $6.8,9.6$ and $11.2 \mu \mathrm{O} \mathrm{O} / \mathrm{h}$ respectively (means of 4 experiments). Dead spermatozoa suspended in $0.15 \mathrm{M}$-sodium chloride consumed significantly less oxygen than did spermatozoa suspended in sodium phosphate or sodium citrate $(P<0.05)$.

\section{Between-bull differences in percentage of dead spermatozoa}

As shown in Table 2, there was a significant correlation between percentage of stained ejaculated spermatozoa and oxidase activity $(r=0.954, P<0.01)$. The regression was $y=0.14$ $+0.1061 x$ where $y=\mathrm{O}_{2}$ consumption in $\mu \mathrm{l} / \mathrm{h}$ and $x=$ percentage of dead spermatozoa. The estimated activity of $50 \times 10^{6}$ dead spermatozoa was $10.8 \mu \mathrm{l} \mathrm{O} / \mathrm{h}$ and of $50 \times 10^{6}$ live spermatozoa was $0 \cdot 14 \mu \mathrm{l} \mathrm{O} / \mathrm{h}$. Whilst untreated epididymal spermatozoa exhibited no oxidase activity, the activity of killed epididymal spermatozoa was similar to that of killed ejaculated spermatozoa. 
Table 2. Oxidase activity $\left(\mu \mathrm{l} \mathrm{O}_{2} / \mathrm{h} / 50 \times 10^{6}\right.$ spermatozoa) of ejaculated and epididymal bovine spermatozoa

\begin{tabular}{|c|c|c|c|c|c|}
\hline \multirow{2}{*}{$\begin{array}{l}\text { Bull } \\
\text { no. }\end{array}$} & \multicolumn{3}{|c|}{ Ejaculated spermatozoa } & \multicolumn{2}{|c|}{$\begin{array}{l}\text { Epididymal } \\
\text { spermatozoa }\end{array}$} \\
\hline & \% Dead & Untreated & Killed & Untreated & Killed \\
\hline 1 & 17 & $2 \cdot 1$ & $10 \cdot 7$ & 0 & 9.8 \\
\hline 2 & 21 & $1 \cdot 3$ & $8 \cdot 8$ & 0 & $10 \cdot 6$ \\
\hline 3 & 25 & $3 \cdot 5$ & $9 \cdot 5$ & 0 & 9.2 \\
\hline 4 & 52 & $6 \cdot 5$ & $10 \cdot 1$ & 0 & 11.4 \\
\hline 5 & 58 & $6 \cdot 1$ & 7.4 & 0 & 8.9 \\
\hline 6 & 68 & $6 \cdot 8$ & $8 \cdot 7$ & 0 & $10 \cdot 7$ \\
\hline Mean & 40 & 4.4 & $9 \cdot 2$ & 0 & $10 \cdot 1$ \\
\hline
\end{tabular}

\section{Discussion}

These results show that aromatic L-amino acid oxidase is located in the bovine sperm tail. Whilst some activity was always present in head preparations, this was probably due to contamination with tails. Release of the enzyme from the cell was affected by the buffer in which dead spermatozoa were suspended. Enzyme release from the cell was low in sodium chloride and sodium phosphate solutions but considerable release occurred in a sodium citrate solution. This difference may be due to the ionic strength of the solutions, that of the sodium citrate solution being 2 -fold greater than that of the other solutions.

Although the solution in which dead spermatozoa were suspended modified oxidase activity, activity being least in the sodium chloride solution, release of the enzyme from the cell is not a necessary prerequisite for activity. There was a significant correlation between the percentage of dead spermatozoa, determined by nigrosin-eosin staining, and oxygen consumption due to L-phenylalanine degradation. This confirms previous observations (Shannon \& Curson, 1972b). However, oxidase activity could not be detected in the epididymal spermatozoa of any of these bulls. This was not due to lack of essential co-factors in epididymal fluid because killed epididymal spermatozoa exhibited similar activity to killed ejaculated spermatozoa. Death of the spermatozoa must therefore have occurred in the upper vas deferens and ampulla and/or as a result of admixture with accessory fluids at ejaculation. Differences between bulls in the percentage of dead ejaculated spermatozoa presumably reffect either a difference in the resistance of the spermatozoa to this environment or a difference between the bulls. Bialy \& Smith (1959) reported that passage of epididymal spermatozoa through the ampulla rendered them susceptible to cold shock. Likewise, the toxic effect of seminal plasma has been well documented (Shannon, 1965; Bennett \& Dott, 1966; Shannon \& Curson, 1972a; Dott, 1974). Further research is required to resolve the relative importance of these factors.

\section{References}

Bennett, J.P. \& Dott, H.M. (1966) An effect of bovine seminal plasma on the impedance change frequency of epididymal spermatozoa collected from the living bull. J. Reprod. Fert. 12, 327-336.

Bialy, G. \& Smith, V.R. (1959) Cold shock of epididymal sperm. J. Dairy Sci. 42, 2002.

Dott, H.M. (1974) The effect of bovine seminal plasma on the impedance change frequency and glycolysis of bovine epididymal spermatozoa. J. Reprod. Fert. 38, $147-156$.

Mann, T. (1964) The Biochemistry of Semen and of the Male Reproductive Tract. Methuen, London.

Shannon, P. (1965) Presence of heat labile toxic protein in bovine seminal plasma. J. Diary Sci. 48, 13621365.

Shannon, P. \& Curson, B. (1972a) The effect of egg yolk 
levels on bovine seminal plasma toxins. Proc. 7th Int. Congr. Anim. Reprod. \& A.I., Munich 4, 1360-1362.

Shannon, P. \& Curson, B. (1972b) Toxic effect and mode of action of dead sperm on diluted bovine semen. J. Diary Sci. 55, 614-620.

Shannon, P. \& Curson, B. (1982) Kinetics of aromatic L-amino acid oxidase from dead bovine spermatozoa and the effect of catalase on fertility of diluted bovine semen stored at $5^{\circ} \mathrm{C}$ and ambient temperatures. $J$. Reprod. Fert. 64, 463-467.

Snedecor, G.W. \& Cochran, W.G. (1972) Statistical Methods, pp. 258-298. Iowa State University Press, Ames.

Received 2 June 1981 